\title{
Špitolių istorijos atspindžiai Rakaučiznos (Ukmergès r.) senkapio tyrimų duomenimis
}

\author{
POVILAS BLAŽEVIČIUS \\ Lietuvos edukologijos universitetas, T. Ševčenkos g. 31, LT-03111 Vilnius \\ El. paštas: povilas.blazevicius@leu.lt \\ JUSTINA KOZAKAITE் \\ Vilniaus universitetas, Universiteto g. 7, LT-01513, Vilnius \\ El. paštas: justina.kozakaite@mf.vu.lt \\ TOMA ZARANKAITE் \\ Vilniaus universitetas, Universiteto g. 3, LT-01513 Vilnius \\ El. paštas: toma.zarankaite@gmail.com
}

\begin{abstract}
Straipsnyje pristatomi naujausi tarpdalykiniai Rakaučiznos senkapio istorijos tyrimai. Šio paminklo archeologinių kasinejimų metu sukauptos informacijos ir palaikų antropologinès analizès rezultatų gretinimas su istoriniais šaltiniais leidžia naujai pažvelgti i XVII a. LDK gyventojų sveikatos bei socialines problemas.
\end{abstract}

Raktažodžiai: LDK špitolių istorija, archeologiniai senkapių tyrimai, XVII a. gyventojų sveikatos būklè, kasdienis gyvenimas

\footnotetext{
IVADAS

Istoriniai šaltiniai įamžina skirtingomis epochomis gyvenusių žmonių patirtis. Vienos iš jų dokumentuotos gausiu rašytiniu paveldu, o kitos, nesulaukusios detalaus aprašymo, palieka daiktinius liudininkus apie praeities gyvenimo akimirkas. Minètą teiginį galètų puikiai iliustruoti mūsų straipsnio objektas - Rakaučiznos (rusèn. Раковъщыны, lenk. Rejkowszczyzna) kaime, esančiame Ukmergès rajono savivaldybèje, per tris kilometrus nuo Pabaisko (lenk. Pobojsk), aptiktas XVII a. senkapis, kurio atžvilgiu rašytiniai šaltiniai tyli, pateikdami tik fragmentiškas žinias apie aptariamą vietovę. Taigi, būtent minètų teritorijų (Rakaučiznos ir Pabaisko) tarpusavio sąveikos, grịstos bažnytiniais, socialiniais bei žemèvaldos aspektais, tampa aktualiais tyrimo uždaviniais siekiant išsiaiškinti gausių palaidojimų Rakaučiznoje atsiradimo priežastis, palaidotų žmonių socialinį statusą, sveikatos būklę ir kitus bendruomenès rekonstrukcijai svarbius duomenis.
} 
Šis tyrimas aktualus siekiant suaktyvinti mikrolokalius tyrimus, kurie dèl istorinių šaltinių retumo Lietuvos istoriografijoje yra beveik neplètojami, tačiau kitų disciplinų (archeologijos ir fizinès antropologijos) dèka gali pateikti unikalios informacijos, padèsiančios pasigilinti i lokalių teritorijų visuomenių raidos savitumus visame Lietuvos Didžiosios Kunigaikštystès (toliau LDK) kontekste. Mūsų tiriamu atveju daug dèmesio skirsime vietovès lokalizavimo problematikai, kadangi išlikusių istorinių šaltinių, susijusių su tiriama vietove, itin reta, todèl labai svarbu nuodugniai patikrinti, ar turima medžiaga iš tiesų kalba apie kasinètą vietovę.

Straipsnis labai svarbus ir antropologiniu požiūriu, mat tai vienas iš retų atvejų Lietuvoje, kai turime neblogai išlikusius vaikų ar net naujagimių palaikus - tai suteikia neịkainojamos informacijos apie mažiausius bendruomenès narius, kurie archeologiniame kontekste tampa tarsi marginalinė jos dalis. Juk antropologinę medžiagą dažniausiai sudaro suaugę individai, tad mažiausieji paprastai lieka už mūsų pažinimo ribų. Kitas svarbus nagrinejjamas aspektas - didelio ligotų asmenų skaičiaus senkapyje interpretacija ir sąsajų su istoriniuose šaltiniuose minima špitole paieška.

Tyrimą pradėsime XVI a., kai pirmą kartą Rakaučizna paminima istoriniuose šaltiniuose, o baigsime XVIII a., susitelkdami $\mathfrak{i}$ archeologinius radinius ir antropologinius tyrimus. Vèlesni laikotarpiai nèra aktualūs tyrimui, kadangi tiesiogiai nesisieja su straipsnio objektu.

Reikšmingiausi šiam tyrimui archeologiniai šaltiniai - 50 kapų su XVII a. būdingomis ¡̇kapėmis. Šių kapų tyrimai 2012 ir 2013 metais, taip pat kaulinės medžiagos antropologinè analizė kaip tik ir inspiravo išsamesnius kompleksinius aptariamo mikroregiono istorijos tyrimus. Istorinių duomenų apie Rakaučiznos kaimą suteikia ir rašytiniai šaltiniai: 17821784 m. Pabaisko dekanato vizitacija, atlikta vyskupo Ignoto Jokūbo Masalskio užsakymu [1], taip pat daug vertingos, tyrimui aktualios informacijos randame Lietuvos Metrikos (toliau LM) 12-oje Užrašymų knygoje [2]. Žinoma, svarbias ižžvalgas leidžia daryti ir vienalaikiai kartografiniai šaltiniai [3, 60-61, 62-63, 64-65, 78-79, 88-89 etc.], iliustruojantys tiriamų vietovių lokaciją.

Šis straipsnis yra pirmasis tyrimas, siekiantis apibendrinti archeologinių kasinejjimų Rakaučiznoje metu rastus duomenis su istoriniuose šaltiniuose randama informacija. Šio pavienio, tačiau dèl palaidotų žmonių patologijų ir įdomaus kiekybinio pasiskirstymo amžiaus grupèse atvejo tyrimas ne tik užpildo Ukmergès (buvusios Vilkmergès, lenk. Wiłkomierz) lokacinių istorijos tyrimų spragas, tačiau leidžia įžvelgti administracinès, socialinès kaitos procesus visoje LDK.

\section{ISTORINĖS ŽINIOS APIE RAKAUČIZNĄ}

LDK vidaus erdvė viduramžiais ir naujaisiais amžiais nebuvo statiška tiek teritoriniu, tiek administraciniu aspektais. Tokiame kontekste tampa svarbu, kada atsirado vienas ar kitas valstybės teritoriją papildęs ūkinis, urbanistinis, administracinis vienetas: valdovo pilis, dvaras, miestas, kaimas, kadangi jų ikūrimas bei plètra turèjo įtakos visos LDK istorinei raidai. Mūsų straipsnio objektas sutelkia dèmesị ị bene lakoniškiausiai šaltiniuose apibūdinamo valstybès segmento - kaimo (mūsų atveju Rakaučiznos) istoriją. Dèl minètos priežasties ir fragmentiškų duomenų šaltiniuose straipsnyje daugiausia kelsime ir tikrinsime hipotezę apie glaudžias Rakaučiznos ir Pabaisko sąsajas, kadangi disponuojama informacija leidžia manyti, jog Rakaučiznoje esantis XVII a. senkapis gali būti susijęs ir su šaltiniuose minima Pabaiske XVIII a. egzistavusia špitole.

Pirmieji Rakaučiznos paminèjimai šaltiniuose datuojami XVI a., todèl galima teigti, jog būtent šiuo metu ir pradeda klostytis minèto kaimo istorija. Tačiau teritorijos paminèjimo 


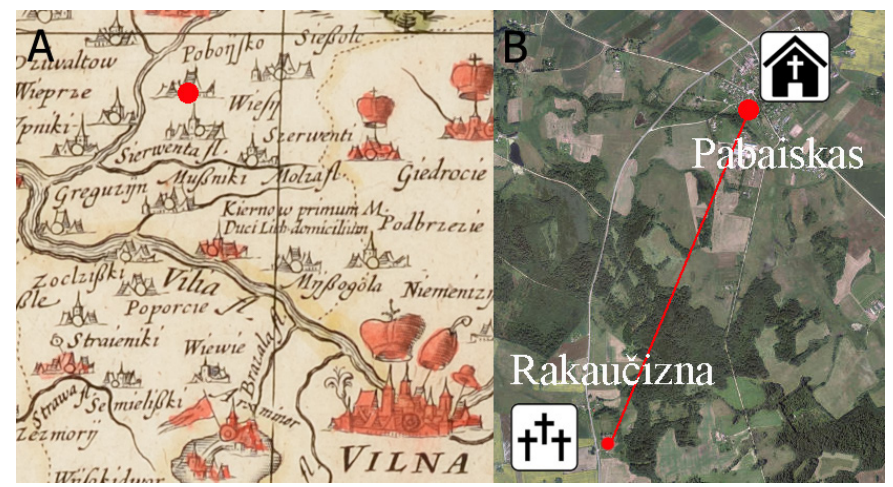

1 pav. Pabaisko miestelis 1613 m. M. K. Radvilos Našlaitèlio žemèlapyje (A) ir XXI a. pr. Pabaisko bažnyčios bei Rakaučiznos senkapio ortofotografinis vaizdas (B) (Povilo Blaževičiaus pav.)

faktas dar nereiškia kaimo ịkūrimo. Antai LM 12-oje Užrašymų knygoje esančiu dokumentu 1522 m. gruodžio penktą dieną Vilniuje Lietuvos didysis kunigaikštis Žygimantas savo raštininkui (djakui) Aleknai Krivecui patvirtina teisę valdyti keturias tuščias žemes Anykščių paviete, duotas jam Anykščių valdytojo Jurgio Astikaičio. Tarp įvardijamų žemių - Jucovščinos (rusèn. Юц,вщъıна), Jagintovščinos (rusèn. Якгинътовъщъьна), Goigoilovščinos (rusèn. Кгоикгоиловъщьына) minima ir Rakovščina (rusén. Раковъщъьна) [2, 175-176], kurią pagal lokaciją, sulyginus vienalaikius kartografinius duomenis (1 pav.), galime laikyti dabartine Rakaučizna. Svarbu atkreipti dèmesį, jog dèl nenusistovejjusios to meto vietovardžių užrašymo tradicijos skirtinguose šaltiniuose tos pačios vietovès ịvardijimas gali varijuoti, tai pastebime ir mūsų tiriamu atveju.

Panašaus pobūdžio ir vẻlesnis mūsų aptariamos vietovès paminèjimas. Po beveik trejų metų, 1525 m. balandžio ketvirtą dieną, suteiktu dokumentu Krokuvoje Lietuvos didysis kunigaikštis Žygimantas dvarioniui Aleknai Krivecui patvirtina teisę valdyti žmones Sterkaičius ir tuščias žemes Anykščių paviete, tarp kurių minima vis dar tuščia Rakovščinos žemè, kol jo tėvonija bus atimta iš maskvènų [2, 369-370]. Abiem aptartais atvejais svarbu atkreipti dėmesị, jog Rakaučizna įvardijama kaip tuščia žemè, dykra, pustynè (rusėn. земля пустовъская). Toks įvardijimas nėra išimtis, kadangi LDK erdvejje aptariamuoju laikotarpiu tokio tipo tuščių, neapgyvendintų ir ūkiškai nenaudojamų ar menkai įdirbtų žemių buvo gana daug $[4,61]$. Taip pat svarbu atkreipti dèmesí, jog ir vietovès pavadinime vyraujanti galūnè su rusèn. priesaga -щ̧ына, o lenk. -szczyzna rodo priklausomybę konkrečiam asmeniui. Mūsų aptariamuoju atveju iki minètų suteikčių greičiausiai Rakaučiznos žemė galejo priklausyti kokiam nors Rakovui iki to laiko, kol pastaroji pateko į Anykščių valdytojo Jurgio Astikaičio dispoziciją. Deja, ankstesnių nei XVI a. paminejjimų šaltiniuose tyrimo metu nepavyko rasti.

Nuosekliam Rakaučiznos vietovès tyrimui trukdo jau minètas istorinių šaltinių fragmentiškumas, kuris leidžia kelti hipotezes, užduoti klausimus, tačiau vos aptikus pėdsakų kontūrus, pastarieji nutrūksta ir vèl „išnyra“ jau visai kitokie ir kitu laiku. Antai 1782-1784 m. Pabaisko dekanato vizitacijoje, atliktoje vyskupo Ignoto Jokūbo Masalskio užsakymu, Rakaučizna ịvardijama jau ne kaip tuščia žemè, o kaimas (lenk. wieś) [1,23]. Taigi galime daryti prielaidą, kad per beveik pusantro šimto metų trukusị laikotarpị, kurio, deja, negalime apčiuopti šaltiniuose, Rakaučiznos administracinis ir ūkinis reikšmingumas lokalioje erdvejje pakilo, ir XVIII a. šaltiniai minètą vietovę ìvardija jau nebe kaip tuščią 
žemę, o kaimą, t. y. ne marginalią teritoriją, o LDK kraštovaizdžiui būdingą sociotopografinị darinị, pasižymintị savitu kultūriniu mikroklimatu $[4,74]$.

Minėtame XVIII a. pab. dokumente teigiama, jog mūsų aptariamas Rakaučiznos kaimas 1782-1784 m. priklausė „didžiai gerbiamam ponui Boguslavišekui Oganovskiui“ [1, 23], kuris tuo metu buvo Vilniaus rotmistras. Svarbu atkreipti dèmesị, jog ne tik Rakaučiznos kaimas XVIII a. pab. buvo Oganovskių giminès įtakos zonoje. Antai iš Trakų teismo regento Pranciškaus Oganovskio skundo prieš Ukmergès pavieto rotmistrą Dizmą Oganovskị $[5,1]$ galime ịžvelgti gana stiprias šios giminès pozicijas Ukmergès paviete.

Taip pat minètoje vizitacijoje pažymima, jog Rakaučiznos kaimas yra apie pusę mylios nuo Pabaisko [1,23]. Svarbu pažymèti, jog LDK mylios ilgis varijavo, o atstumo matas buvo santykinis skaičiavimo vienetas. XVII-XVIII a. LDK ir Lenkijoje naudotų mylių ilgis visuomet svyravo apie $7 \mathrm{~km}$, todèl Rakaučiznos kaimo lokacijos įvardijimas šaltinyje (apie $3 \mathrm{~km}$ nuo Pabaisko) atitinka šių dienų realijas.

Iš Pabaisko dekanato vizitacijos matyti, kad XVIII a. pabaigoje čia vis dar veikè parapinè bažnyčia, pastatyta dar 1436 m. [6], o greta jos buvo ir špitole [1, 8]. Anot Martyno Jakulio, nuo XVII a. „,vis daugiau špitolių buvo steigiama ne tik LDK miesteliuose, bet ir provincijoje prie parapinių bažnyčių. Galutinai špitolių tinklas susiformavo maždaug XVIII a. viduryje ir antroje puseje“ " $[7,1]$.

Funduojamos špitolès dažniausiai nebuvo didelès, skirtos kelioms dešimtims vargšų [7]. Iš minèto 1782-1784 m. Pabaisko dekanato vizitacijos rašto matome, kad aptariamuoju laikotarpiu išlaikytinių skaičius buvo minimalus, o pati špitolè: „fundacijos neturi, tik špitolès namas, kuriame gyvena zakristijonas ir vienas senelis, dvi senelès, jiems viskas yra gerai. Jų pareigos lankytis bažnyčioje, maitinimą turi [gauna] iš parapijos klebono turto" $[1,8]$. Mūsų tiriamas atvejis puikiai dera prie bendro LDK konteksto, kai dauguma špitolių veikè prie parapinių bažnyčių, prižiūrimos klebonų $[7,1]$.

\section{ARCHEOLOGINIAI TYRIMAI IR PALAIKŲ ANTROPOLOGINĖ ANALIZE்}

Apie senkapi Rakaučiznos kaime, esančiame Ukmergès rajone, greta rajoninio kelio Musininkai-Čiobiškis-Gelvonai-Vytinè (4305), sužinota neseniai. Gyventojams tvarkant sodybos aplinką ir kasant griovị nuotekoms 2005 m. rasti žmonių kaulai. 2006 m. buvo ištirtos ir pirmosios trys $5 \times 2 \mathrm{~m}$ dydžio perkasos, tačiau kapų jose nerasta [8]. Ištyrus gyventojų surinktus žmonių kaulus nustatyta, kad jie priklausè ne mažiau kaip 4 asmenims: apie $5 \mathrm{~m}$. ir 5-10 m. vaikams, $20 \mathrm{~m}$. bei 40-50 m. moterims [9, 531]. $2012 \mathrm{~m}$. Lietuvos edukologijos universitetui kartu su Generolo Jono Žemaičio Lietuvos karo akademija ieškant Pabaisko mūšyje žuvusių karių kapų, buvo nuspręsta tirti ir Rakaučiznos senkapị. Ištyrus $90 \mathrm{~m}^{2}$ plotą rasti kapai ir jų ikkapès atskleidè, kad laidojimo paminklas datuojamas XVII a. ir nèra susijęs su XV a. vykusiu Pabaisko mūšiu [10], tačiau ịdomi archeologinė ir antropologinė medžiaga paskatino pratęsti tyrimus.

Archeologinių tyrimų metu 2012 ir 2013 m. buvo ištirtos keturios perkasos, sudarančios „T“ pavidalo plotą, kurių bendras plotas - $150 \mathrm{~m}^{2}$ Tyrimų teritorija apemė dali kalvos, esančios apytiksliai $160 \mathrm{~m}$ i r rytus nuo Žirnajos upelio (2 pav.). I perkasa buvo orientuota R-V kryptimi ir sudarè savotišką kalvos šlaito pjūvị nuo kalvos aikštelès viršaus iki jos pagrindo. II-IV perkasos buvo išdèstytos kalvos viršuje, palei rytinị jos šlaitą. Didžioji dalis kapų, kaip ir reikejjo tikètis, buvo viršutinejje kalvos dalyje, du kapai aptikti papèdejje, o šlaite jų nerasta. Iš viso atidengta bei ištirta 50 kapų. Lauko tyrimų metu atrodė, kad kapai senkapio teritorijoje išsidèstę be jokios tvarkos, chaotiškai. Tačiau vèliau, sutelkus dèmesị 


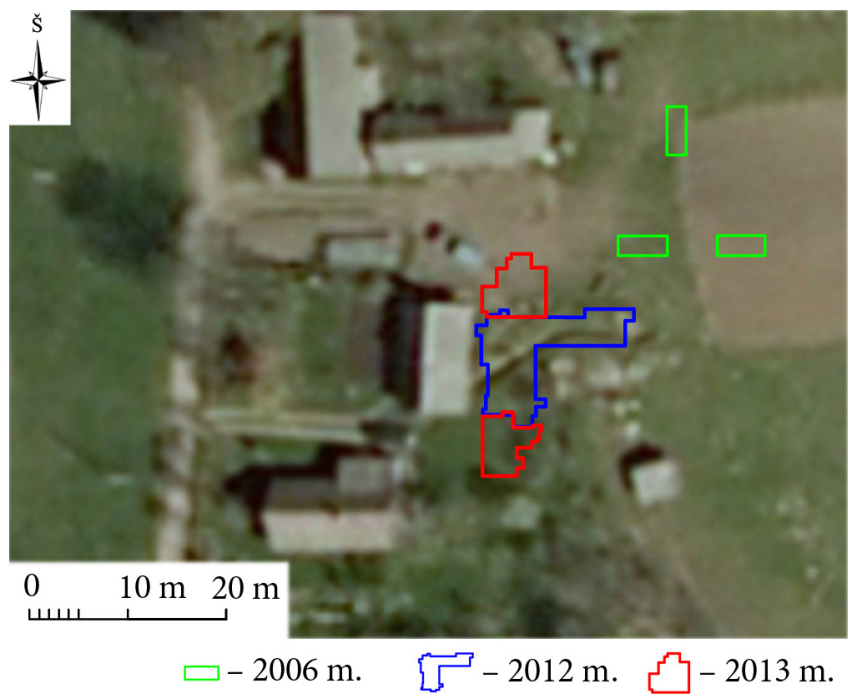

2 pav. Tirtu perkasų Rakaučiznos senkapyje situacijos planas (P. Blaževičiaus ir Aušros Zalepūgienès pav.)

i suaugusiųjų kapus, pastebètas jų išsidèstymas savotiškomis lenktomis eilèmis. Susidaro vaizdas, kad senkapyje suaugusieji buvo laidojami į PR-ŠV orientuotomis eilemis, galvomis i̇ V su nedideliu nuokrypiu ị P. Pažymejjus hipotetines kapų eilių linijas paaiškèjo, kad ir didžioji dalis vaikų kapų „telpa“ jų ribose (3 pav.).

Reikia paminèti, kad tyrimų metu maišytos žemès sluoksniuose surinkta ir nemažai antropologinès medžiagos iš suardytų palaidojimų, tačiau abejojant rezultatų patikimumu informacija apie suardytus kapus neịtraukta ị straipsnyje analizuojamą duomenų imtị. 95 proc. kapų orientuoti $\mathrm{V}$ kryptimi su nedidele paklaida. Išsiskyre tik kapų Nr. 13 ir Nr. 46 kryptis: pirmasis orientuotas $\mathfrak{i} \check{S}$, antrasis $-\mathfrak{i}$ PV. Tai 3-6 m. ir $8 \mathrm{~m} . \pm 24$ mèn. vaikų kapai, gal todèl juos laidojant ir nebuvo taip griežtai laikomasi krikščionims būdingo tradicinio

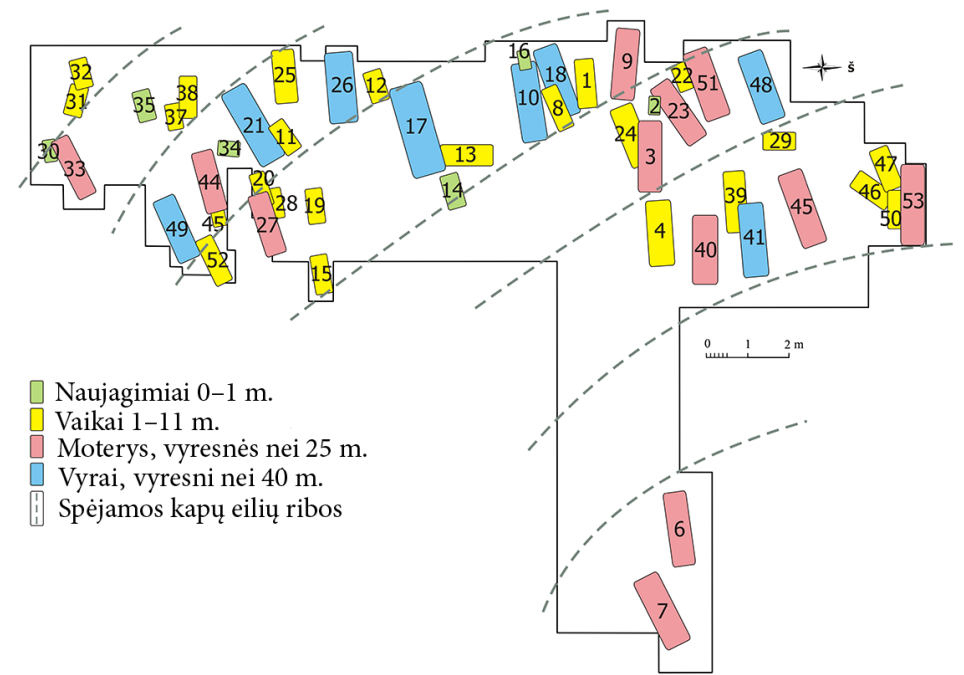

3 pav. Kapų išsidèstymo pagal amžių bei lytis Rakaučiznos senkapyje situacinis planas (P. Blaževičiaus pav.) 
orientavimo. Labai skyrèsi kapų gylis. Vaikai laidoti negiliai - 30-60 cm gylyje, o kai kurie ir vaikų, ir suaugusiųjų kapai (Nr. 1-4, 12,13) aptikti vos kelių ar keliolikos centimetrų gylyje. Tokią situaciją paaiškino sodybos šeimininkas: XX a. antrojoje puseje dalis kalvos viršaus ir šlaito buvo lyginta buldozeriu. Matyt, tuo metu nustumdžius žemes buvo atidengta dalis kapų, o kiti atsidūrẻ kelių ar keliolikos centimetrų gylyje. Pietinejje kalvos aikštelès dalyje, kur nevyko tokie intensyvūs žemès paviršiaus planiravimo darbai, suaugusiųjų kapai fiksuoti 60-90 cm gylyje. Tyrimų metu nustatyta, kad dalis suaugusiųu (kapai Nr. 6, 9, 10, 17, $18,26,45,48)$ laidota lentiniuose karstuose. Vaikai, kaip ir likusieji suaugusieji, regis, laidoti be karstų, paprasčiausiai susupant ị audinị. Tokio audinio liekanų rasta prie kelių metalinių dirbinių - monetų bei žvangučio. Šios ịkapès buvo per kelis centimetrus virš palaikų, tad gali būti, kad jos įdètos / įmestos palaikus jau paguldžius kapo duobejje. Galima manyti, kad tai ne drabužių, o būtent laidojimo drobulès fragmentai.

Kalbant apie mirusiųjų padètị kapuose, pažymètina, kad visi jie palaidoti gulomis ant nugaros, ištiestomis kojomis. Kapuose, kuriuose buvo galima nustatyti rankų padèti, fiksuotas ịprastinis senkapiams vaizdas - palaidotụjų rankos ištiestos, priglaustos prie šonų arba kiek sulenktos per alkūnes, o plaštakos sudètos dubens srityje.

Ikapių aptikta tik šešiuose kapuose. $11 \mathrm{~m} . \pm 30$ mẻn. amžiaus vaiko kape Nr. 3 prie dešiniosios kojos pėdos rasta metalinė bato pasagèle, o kaklo srityje surinktos smulkių mèlyno stiklo karoliukų apvaros liekanos. Krūtinès srityje, palei stuburą, aptiktos šešios metalinès kilpelès drabužiui ar audeklui susegti. Virš dešiniojo peties, greta ne vietoje gulinčio vieno stuburo slankstelio, rasta apskrita vario lydinio segè. Nors ịkapés nèra tiksliai datuojamos, remiantis analogijomis galima teigti, kad tai yra XVII a. II-III ketv. dirbiniai [11, 82, 83]. Taip pat galima datuoti ir ịkapes iš 10 m. \pm 30 mèn. amžiaus vaiko kapo Nr. 4 [11, 82, 250, 298]. Šiame kape, dešinio žastikaulio viršuje, rasta apvali balto metalo segè, kaklo srityje - 212 skirtingo dydžio stiklinių karoliukų apvara, pakaušio srityje - fragmentiškai išlikusio medžiaginio apgalvio dalys.

40-50 metų amžiaus vyro kape Nr. 10, lentinio karsto viršuje, rastas LDK Jono Kazimiero šilingas, nukaltas $1666 \mathrm{~m}$. Vilniuje. Minètas šilingas ir tokios pat monetos falsifikatas aptiktas ir 40-50 metų vyro kape Nr. 18. Viena moneta ir žvangutis tyrimų metu surasti ir 6 m. \pm 24 mèn. vaiko kapelyje Nr. 38. Apvalus vario lydinio žvangutis su prilipusio audinio fragmentu rastas apytiksliai $5 \mathrm{~cm}$ virš kairiojo klubo, o $25 \mathrm{~cm}$ ị P nuo kaukolès rastas 1624 m. nukaltas Zigmanto Vazos III šilingas (4 pav.). Atsižvelgiant ị ịkapių padètį, reikia manyti, kad abi buvo ne prie kūno, o ịdètos ị kapo duobę ją užkasant. Kape Nr. 39, kuriame palaidotas $11 \mathrm{~m} . \pm 30$ mẻn. amžiaus vaikas, rasti du Jono Kazimiero šilingai. Prie vieno jų, nukalto $1666 \mathrm{~m}$., buvo surastas prilipęs ir užsikonservavęs nedidelis audinio gabaliukas. Kitas aplūžęs šilingas (jo kalimo metai neaiškūs) rastas po dešine kaukolès puse. Mirusiojo

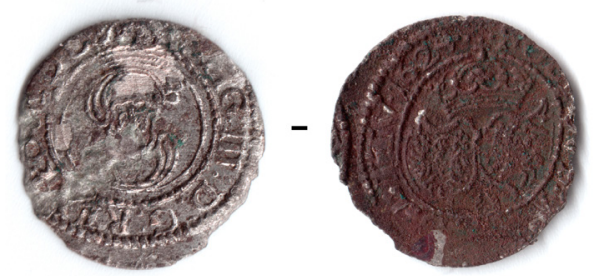

4 pav. Zigmanto Vazos III šilingas (1624 m.), rastas $6 \mathrm{~m} . \pm 24$ mèn. amžiaus vaiko kape Nr. 38 (P. Blaževičiaus nuotr.) 


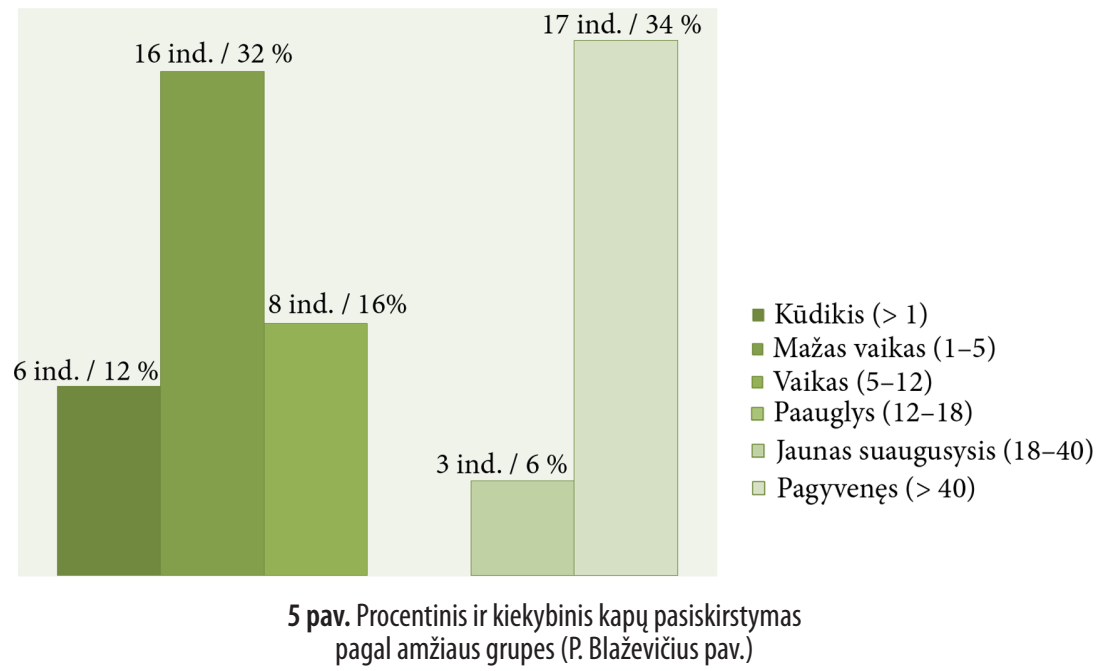

kaklo ir krūtinės srityje aptikti 89 smulkūs žydri ir tamsiai mèlyni stiklo karoliukai bei ovalo formos stiklinio medaliono, įrèminto alavo ar švino lydinio rèmeliu, su kilpute liekanos. Atrodo, kad karoliukai ir medalionas sudare vieną apvarą. Vienos stipriai korozijos paveiktos varinès monetos fragmentas rastas ir $6 \mathrm{~m} . \pm 24$ mèn. amžiaus vaiko kape Nr. 52 .

Apibendrinant tyrimų metu aptiktas kelių lentinių karstų liekanas bei skurdokas įkapes ir net atsižvelgiant $\mathfrak{i}$ bendras XVI-XVII a. dedamų ikapių tradicijos nykimo tendencijas, galima teigti, kad palaidotieji greičiausiai buvo menkai pasiturintys ir žemesnio socialinio statuso žmonès. Tą savotiškai patvirtina ir antropologiniai palaikų tyrimai, kurių metu buvo atlikta vizuali palaikų lyties, amžiaus $\left({ }^{*}\right)$ ir patologijų diagnostika.

Ištyrus 50 kapu $i$ akis pirmiausia krito tai, kad net 60 proc. palaidotujų yra vaikai iki 12 metų. Apžvelgdami palaidojimus pagal mirusiųjų amžiaus grupes matome, kad kūdikiai sudaro 12 proc., maži vaikai - 32 proc., vaikai - 16 proc., visai nerasta paauglių kapų, jauni suaugusieji sudaro 6 proc., o pagyvenę - 34 proc. (5 pav.). Pirmiausia stebina didžiulis vaikų kapų procentas. Dažniausiai jų randama nedaug dèl kelių aspektų: aplinkos poveikio (dirvožemio rūgštingumas, karščio ir šalčio periodai, santykinis drègmès kiekis ir pan.) bei skeleto specifikos - smulkūs ir trapūs kaulai greičiau paveikiami tafonomiškai. Tačiau ir ịvertinus visas galimas fizinio vaikų kapelių sunykimo priežastis, jų senkapyje rasta neįprastai daug.

Žvelgdami ị paleodemografinius Rakaučiznos senkapio duomenis ir pagal stacionarios populiacijos modelị apskaičiuodami tikètinos (kai kūdikių ir mažų vaikų iki $5 \mathrm{~m}$. mirtingumas siekia 45 proc.) [12] bei nustatytos populiacijos amžiaus struktūros santykị matome didžiulius neatitikimus. Pagal senkapio duomenis, rekonstruotoje populiacijoje akivaizdžiai per mažai vaikų nuo 0 iki $15 \mathrm{~m}$. ir per daug suaugusiujjų nuo $20-25$ iki 50-55 m. (6 pav.). Akivaizdu, kad senkapis reprezentuoja nestandartinę bendruomenę arba išskirtinį laikotarpị, ịvykius. Peršasi mintis, kad gausybẻ vaikų galèjo mirti dèl tikrai prastų gyvenimo sąlygų, susijusių su lokaliomis mikroregiono problemomis, kurioms ịtakos galejo turèti ir globalūs

* Lytis buvo nustatoma pagal kokybinius skeleto lytinio dimorfizmo rodiklius, o amžius - pagal kaukolès siūlių, ilgụjų kaulų epifizių sukaulèjimą, dubenkaulio ausinio paviršiaus ir gaktikaulio pokyčius. Vaikų amžius nustatytas pagal išdygusius dantis. 


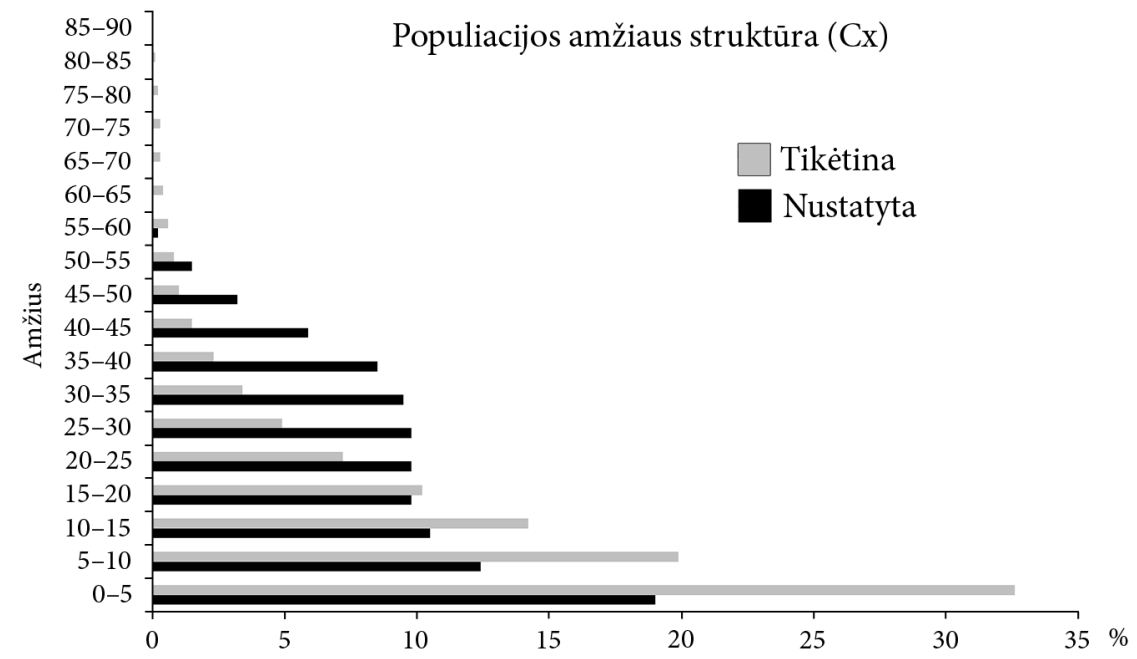

6 pav. Tikètina ir nustatyta tirtos Rakaučiznos populiacijos amžiaus struktūra (P. Blaževičius pav.)

veiksniai. Reikia nepamiršti ir istoriografijoje Tvanu įvardijamo laikmečio (XVII a.), kada Abiejų Tautų Respublika buvo nusiaubta ir nualinta nuolatinių svetimų Maskvos ir Švedijos kariuomenių puldinèjimų. Ilgai užsitęsę karai neleido normaliai funkcionuoti tiek politiniam, tiek ekonominiam valstybès gyvenimui. Sutrikus vidinei infrastruktūrai, valstybès gyventojai ne sykị kentejjo nuo bado, o tai neretai sukeldavo ir epidemijų protrūkius. Gali būti, kad nusilpusius nuo nevisavertės mitybos vaikus „iššienavo“ kokia nors infekcinè liga, nepaliekanti požymių kauluose. O gal tai pamestinukai ar našlaičiai, kurie buvo globojami netoliese buvusioje Pabaisko špitolèje? Šių hipotezių šiandien pagrịsti dar negalime, juolab kad ir istoriniuose šaltiniuose vaikai neminimi.

Svarbios informacijos apie vietos gyventojų bendruomenę teikia palaidotųjų sveikatos tyrimai. Osteologinès medžiagos analize nustatyta santykinai daug patologijų. Apibendrinant visus mirusiųjų duomenis matyti, kad iš 50 net 22 (44 proc.) nustatytos vienokios ar kitokios patologijos: devyni (18 proc.) mažakraujystės atvejai, dviem asmenims (4 proc.) diagnozuotas tretinis sifilis, dar 12-ai (24 proc.) - ívairaus laipsnio artritiniai pokyčiai, nespecifiniai infekciniai susirgimai, įvairios, kartais daugybinès, traumos (7 pav.).

Mažakraujystės atvejai nustatyti daugiausia 3-11 m. vaikams (7 atvejai) ir dviem 30-40 bei $50 \mathrm{~m}$. moterims. Mažakraujystè, arba anemija, kyla sutrikus eritrocitų gamybai ar gerokai sumažejus hemoglobino kiekiui kraujyje. Paprastai liga siejama su geležies trūkumu mityboje, nors galimos ir kitos priežastys - viduriavimas, žarnyno parazitinė infekcija, ankstyvas nujunkymas ar tam tikros rūšies produktų, trukdančių pasisavinti geležị, vartojimas [13]. Sergantieji mažakraujyste paprastai nejaučia ryškaus sveikatos sutrikdymo, tačiau kankina nuolatinis nuovargis, silpnumas, vangumas ar oro trūkumas. Ypač agresyvi ar pažengusi šios ligos forma pasireiškia netolygiu širdies ritmu ir jos padidėjimu. Naujagimių, kuriems pasireiškia anemija, vystymasis paprastai būna sutrikęs. Nemažas anemija sergančiųjų kiekis rodo, kad palaidoti žmonès yra iš prasčiausiai gyvenančios - neturtingiausios - visuomenès dalies.

Kita nedažna patologija yra sifilis, dar žinoma kaip „prancūziška liga“. Rakaučiznos senkapyje rasti du vèlyviausia, tretine, šios ligos stadija sirgę žmonės. Nors kapas Nr. 27 atidengtas stipriai apardytas, išlikusi tik kaukolè ir pečių linijos kaulai, pavyko nustatyti, kad čia palaidota 




7 pav. Kapu išsidèstymo pagal nustatytas patologijas Rakaučiznos senkapyje situacinis planas (P. Blaževičiaus pav.)

25-35 m. moteris. Jai diagnozuota abiejų nosikaulių ir visos nosies ertmės stiprus suardymas bei išplitę uždegiminiai procesai. Panašūs pokyčiai matyti ir viršutinio žandikaulio gomuryje. Dažna sifilio palydovė - parodontozé, varginusi ir šią moterị, t. y. daugelis dantų buvo iškritę gerokai prieš mirtị, o krūminių dantų šaknys jau buvo atviros ir klibejjo (8 pav.). Apibendrinant visus požymius, galima teigti, kad ši moteris sirgo tretiniu sifiliu (rhinopharyngitis mutilans). Šia lytiniu būdu plintančia liga sirgo ir vos už kelių metrų kape Nr. 49 palaidotas 50-55 m. vyras, kuriam antropologinių tyrimų metu taip pat nustatytas tretinis sifilis. Apie tai bylojo skelete ryškiai matomi gumu (giliai poodyje susidarę mazgai, vẻliau virstantys skausmingomis opomis, kurioms sugijus lieka randai; gumos aptinkamos ir kauluose) pèdsakai ir pažeidimai: abiejų menčių, krūtinkaulio, žastikaulio, dilbio bei plaštakos kaulų, šlaunikaulių, blauzdos ir pėdų kaulų. Kitas, tik sifiliui būdingas, požymis yra carries sicca, pastebimas kaktikaulio srityje, abiejų pusių momenkauliuose ir kairès pusès skruostikaulyje (9 pav.). Šis individas taip pat turejjo sugijusị kairès pusès vieno šonkaulio lūži bei stuburo pažeidimą - Šmorlio mazgus,

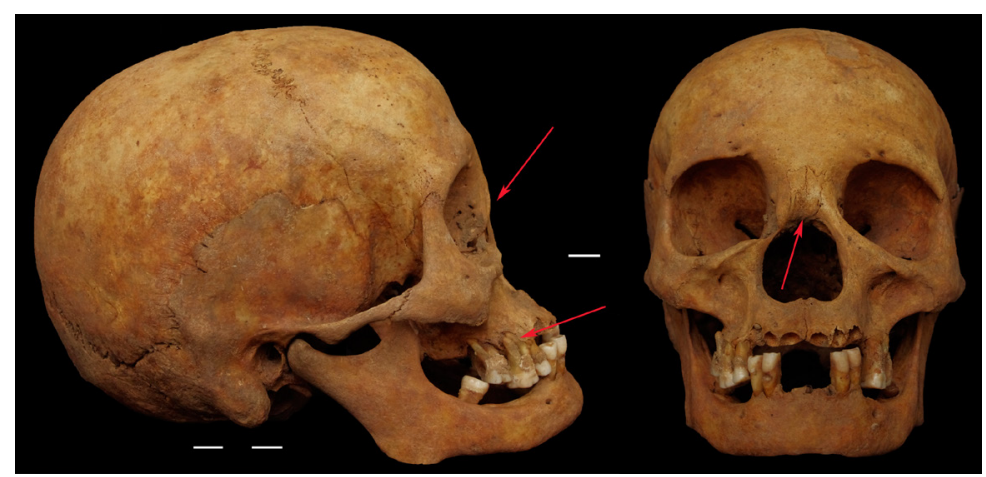

8 pav. Bendras $25-35 \mathrm{~m}$. amžiaus moters kaukolès vaizdas (kapas Nr. 27) su sifiliui tipiška „balno nosimi“ (J. Kozakaitès nuotr.) 
t. y. tarpslankstelinių diskų išvaržas dèl didelio fizinio krūvio, svorio ir kt.

Špitolèse prieglobstị suradusių špitolininkų ligų spektras buvo itin platus - nuo ịvairių infekcinių ir vidaus ligų, ìvairių sužalojimų ar negalavimų iki psichikos negalios ar venerinių ligų („prancūziškos ligos“ - sifilio) [7]. Pastarosios ligos pedsakų aptinkame ir Rakaučiznos senkapyje. Yra atvejų, kai sergančios moterys šią ligą perduoda ir savo naujagimiui. Sifiliui būdingos kelios stadijos su kiekvienai jų tipiškais simptomais. Vieni pirmųjų požymių yra gerklès ir raumenų skausmai, karščiavimas, limfmazgių padidejimas ir nedidelis bèrimas. Progresuojant ligai visi požymiai paaštrèja - bèrimas plinta po visą kūną, virsta ilgai negyjančiomis opomis, slenka plaukai, kieteja limfmazgiai. Tretinis sifilis yra paskutiné ligos stadija, kurios metu pakenkiama kaulams, centrinei nervų sistemai, širdžiai ar kraujagyslèms. Žmogus netenka regèjimo, sutrinka psichika.

$\mathrm{Du}$ individai iš Rakaučiznos kentejo nuo paskutinès šios specifinès infekcinès ligos stadijos. Dèl vidinių ir išorinių viso kūno opų jiems neabejotinai reikejjo nuolatinès priežiūros (10 pav.). Lieka tik neaišku, ar visuomenè atsiribodavo nuo tokių ligonių juos izoliuodama bei ištremdama ị atokias vietas, pavyzdžiui, špitoles. Nuo XV a. pab. Lietuvoje žinoma ši liga dažniau identifikuojama didesnių miestų laidojimo paminkluose. Alytuje sifiliu galèjo būti užsikrètę 2-3 proc. gyventojų, Vilniuje - net 7-11 proc. miestelènų, o aukštuomenejje - dar daugiau [14]. Kaimo vietovejje ši liga itin reta. Rakaučiznos kapinynas - įdomi išimtis. Pagal statistiką, nedidelei kaimo gyvenvietei toks sergamumas yra didelis. Tad šios ligos atvejai byloja, kad senkapyje laidoti žmonès ne tik iš neturtingiausios visuomenès dalies, bet dar ir išskirtinai ligoti.

Dvylika kapų su kitomis fiksuotomis patologijomis tarsi patvirtina bendrą vaizdą, bylojantị prastą palaidotujų sveikatą ir sunkias gyvenimo sąlygas. Atsižvelgiant i patologijas ir jų poveiki bendrai organizmo būklei, jas galima suskirstyti ir kelias grupes. Pirma - nedidelès patologijos,

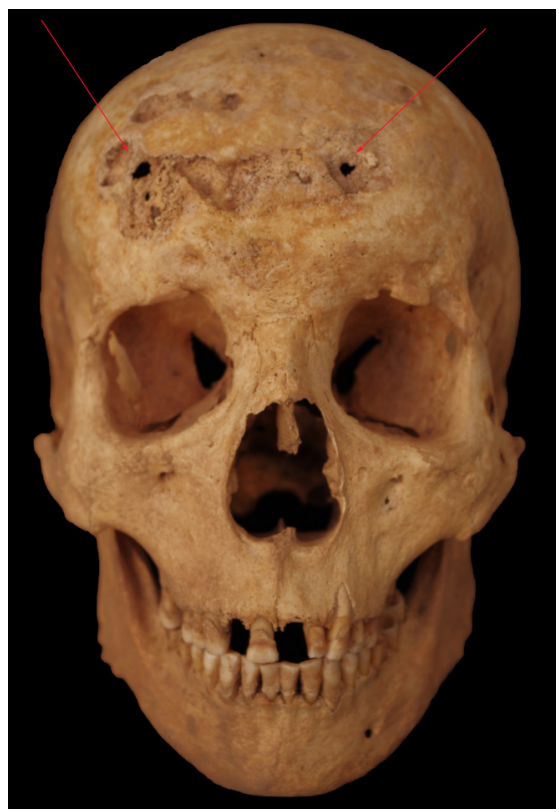

9 pav. Kape Nr. 49 palaidoto $50-55 \mathrm{~m}$. vyro kaukolè su sifilio požymiais - carries sicca kaktikaulio srityje (J. Kozakaitès nuotr.)

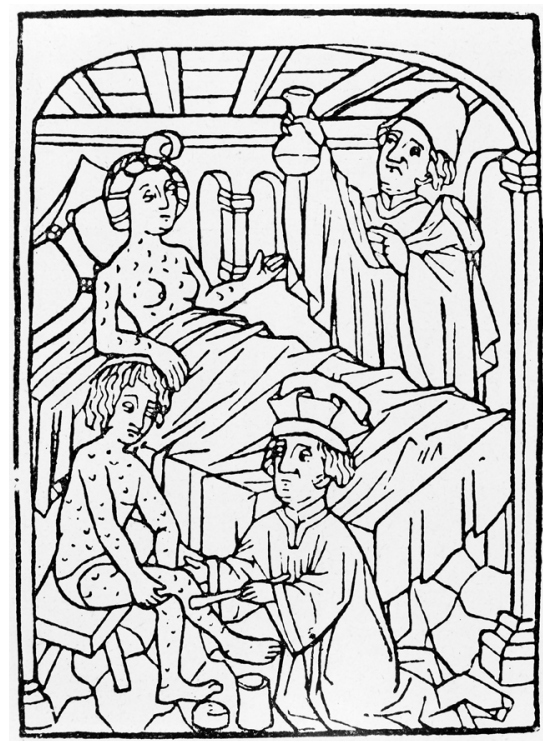

10 pav. $1497 \mathrm{~m}$. medžio raižinys, vaizduojantis gulinčią moterį ir sẻdintį vyrą, kurių kūnai nusèti tretiniam sifiliui būdingomis atviromis opomis. Vienas gydytojas laiko indą su tyrimams paimtu moters šlapimu, kitas tepa vyro koją tepalu su gyvsidabriu [15] 
nemažinančios žmogaus darbingumo ir nebloginančios gyvenimo kokybès. Tokiomis galima laikyti periostitą (nespecifinis antkaulio uždegimas, kurị gali sukelti nedidelis sumušimas, padidèjęs krūvis ir pan.), užfiksuotą kapuose Nr. 10, 17, 33 ir 44; sugijusius lūžius be ryškių pakitimų kapuose Nr. 10, 24 ir 33; osteochondromas (kremzlinio ir kaulinio audinio nepiktybinius navikus) kape Nr. 51; spondilolizę (slankstelio lanko atitrūkimas nuo slankstelio kūno; dažniausia priežastis - nuolatinis fizinis krūvis ar staigi trauma) kape Nr. 41.

Antrai grupei galima priskirti patologijas, kurių poveikis yra ilgalaikis ir juntamas tolesniame žmogaus gyvenime. Tokiais pakitimais skelete įvardijami netikèti padariniai, kurie negydomi gali tapti chroniški, pvz., aktyvus abscesas (t. y. žmogus mirè ji turẻdamas) kape Nr. 7; Šmorlio mazgai kapuose Nr. 7 ir 49; dẻl uždegimo suaugę kaklo slanksteliai, sukeliantys nutirpimą, maudimą - kape Nr. 48; dèl sutrikusios kraujotakos atskilęs žastikaulio tolimojo galo kremzlès gabaliukas, todèl galimas sąnario tinimas - kape Nr. 21; lūžius su ženkliais artritiniais pokyčiais - kape Nr. 9. Kitos šios grupès patologijos yra degeneracinès kilmès - siejamos su amžiumi, t. y. pečių, rankos, plaštakos, dubens lanko, kojų ir pèdų artritas, fiksuotas Nr. 44 ir 45 kapuose; visų slankstelių specifiniai artritiniai pažeidimai (osteochondrozè ir spondiloartrozé), lemiantys nejudrumą, sustingimą, maudimą - kapuose Nr. 9, 18, 48, 53. Reta, tačiau įdomi anatominè variacija yra concha bullosa, arba padidèjusi vidinès nosies kriauklè (11 pav.). Ją kentėjęs individas, rastas kape Nr. 41, galëjo turèti nedidelių kvèpavimo sutrikimų ir turèjo... knarkti.

Trečiai grupei priskirtini pokyčiai, kurių visuma turejo gerokai paveikti individo darbingumą ar savijautą. Šiai grupei priklauso trys asmenys: du jau anksčiau minėti sifiliu sirgusieji (kapai Nr. 27 ir 49) ir kape Nr. 26 palaidotas per 50 metų amžiaus vyras. Pastarajam diagnozuoti ịvairūs daugybiniai sužalojimai: abiejų nosikaulių sugijęs lūžis, kairiojo raktikaulio petinio galo dalinis lūžis, šlaunikaulio kaklo lūžis su ryškia deformacija ir artritiniais pokyčiais (12 pav.), abiejų šlaunikaulių ir blauzdikaulių diafizių periostitas, dešinès pusès dviejų šonkaulių sugiję lūžiai, III-VII kaklo slankstelių osteochondrozé, VI-IX krūtinès slankstelių spondiloartrozè ir XI slankstelio Šmorlio mazgai, V slankstelio keterinès ataugos sugijęs lūžis (kritimas ant nugaros ar stiprus smūgis $\mathfrak{i}$ nugaros juosmens dalį?). Visas stuburas turèjo ryškius osteofitus - kaulines ataugèles, susidarančias dèl amžiaus ar traumos (13 pav.). Aptariamas vyriškis kentėjo nuo senatvès pokyčių visame kūne ir patyrè nemažai traumų. Neaišku, ar visi lūžiai buvo vieno nelaimingo ịvykio pasekmè, ar „kaupti“ visą gyvenimą, bet dauguma jų sietini su nelaimingu atsitikimu (išskyrus nosies ir šonkaulio lūžius, kurie yra smurtinès kilmès). Pirmosios dienos po patirto sužalojimo yra sunkios, nes lūžio vietą skauda, sunku ją judinti, ji būna patinusi. Netgi po menkiausios traumos turi praeiti kažkiek laiko, kad pagerètų bendra organizmo būklè ir grị̌žtų darbingumas.

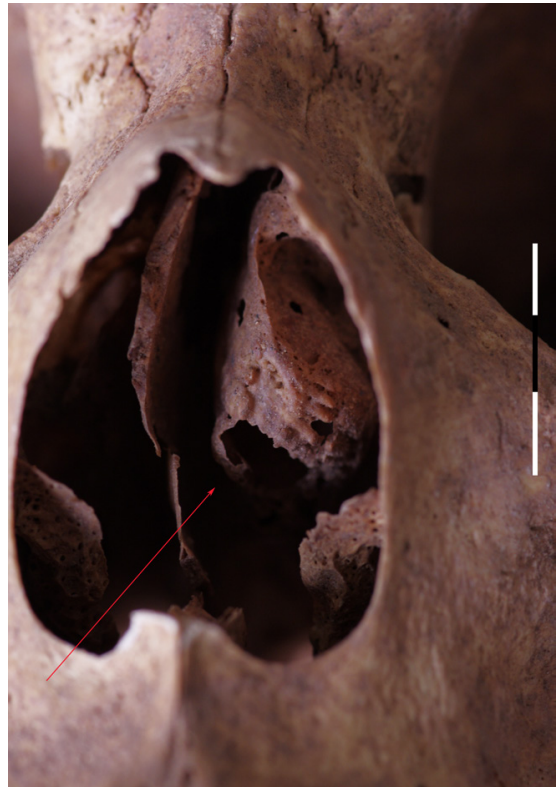

11 pav. Vyras su concha bullosa, arba padidejusia vidinés nosies kriaukle, kapas Nr. 41 (J. Kozakaites nuotr.) 


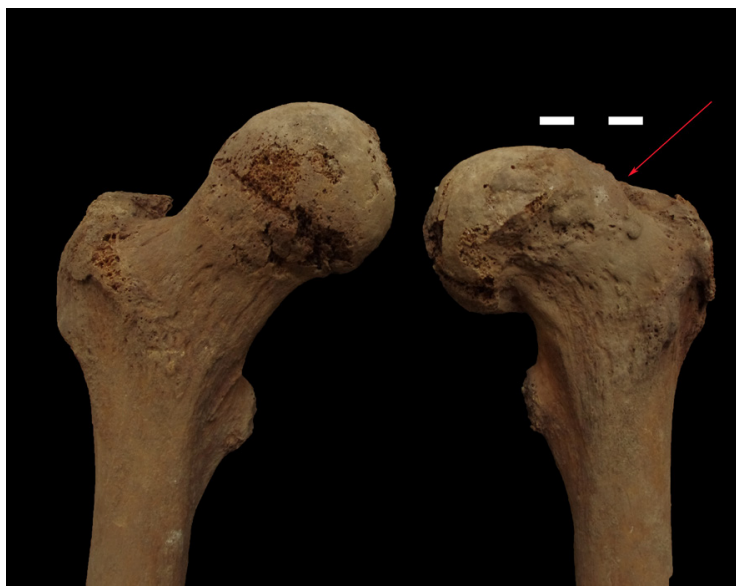

12 pav. Kape Nr. 26 palaidoto vyresnio nei $50 \mathrm{~m}$. amžilaus vyro kairiojo šlaunikaulio kaklo lūžis. Palyginimui - dešinės kojos šlaunikaulis (J. Kozakaites nuotr.)

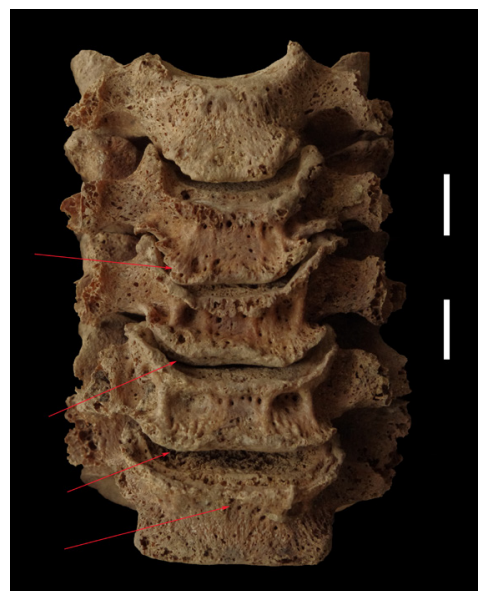

13 pav. Kape Nr. 26 palaidoto vyresnio nei $50 \mathrm{~m}$. amžiaus vyro kaklo slankstelių osteofitai (J. Kozakaites nuotr.)

Gausios ir ịvairios mirusiųjų traumos, matyt, iš dalies trukdžiusios gyviesiems visavertiškai pasirūpinti savimi, taip pat yra argumentas, patvirtinantis špitolès globotinių laidojimą senkapyje. Mat šis aspektas (t. y. negalejimas pasirūpinti savimi ir dirbti) taip pat buvo būtina prièmimo ị špitolę sąlyga [7].

\section{IŠVADOS}

1. Pirmieji Rakaučiznos (rusèn. Раковъщъына, lenk. Rejkowszczyzna) paminèjimai šaltiniuose datuojami XVI a., todèl galima teigti, jog būtent šiuo metu ir pradeda klostytis minèto kaimo istorija.

2. Rakaučiznos administracinè ir ūkinè reikšmè lokalioje erdvèje palaipsniui kilo, ir XVIII a. šaltiniai minètą vietovę ìvardija jau nebe kaip tuščią žemę (rusėn. земля пустовъская), o kaimą, t. y. ne marginalią teritoriją, o LDK kraštovaizdžiui būdingą sociotopografinị darinị, pasižymintị savitu kultūriniu mikroklimatu.

3. Rakaučiznos istorinei, socialinei raidai įtakos turèjo glaudi didesnès apgyvendintos vietovès - Pabaisko kaimynystè, o rašytiniuose šaltiniuose fiksuojamos špitolès ligoniai, atsižvelgiant ị jų ligotumą ir deformacijas, greičiausiai laidoti Rakaučiznos senkapyje.

4. Senkapyje palaidotų žmonių antropologiniai tyrimai rodo, kad Rakaučiznoje laidoti daugiausia vaikai iki 12 m., neturtingiausi, silpnos sveikatos bendruomenès atstovai, taip pat sunkiai bei pavojingomis ligomis sirgę žmonès. Kūdikiai iki vienerių metų sudaro 12 proc., maži vaikai - 32 proc., vaikai - 16 proc. Paauglių kapų laidojimo paminkle nerasta, jauni suaugusieji sudaro tik 6 proc., o pagyvenę (vyresni nei $40 \mathrm{~m}$.) - net 34 procentus.

5. Atsižvelgiant ị netradicinị palaidotų žmonių amžiaus grupių santykị Rakaučiznos senkapyje, ìvairių traumų bei infekcinių ligų gausumą, galime daryti prielaidą, jog senkapyje buvo laidojami ir (o gal - tik) Pabaisko špitolès globotiniai bei pacientai. Tą tarsi patvirtina ir žinios, kad špitolèse mirusių žmonių laidojimui neretai buvo pasirenkamos atokesnès vietovès nuo tankiau apgyvendintųjų. Be to, neretai špitolès, be gydymo, teikdavo ir prieglaudos funkcijas. Jos priglausdavo pamestinukus ar našlaičius, nusilpusius senolius ar vyresnio amžiaus netekejjusias, silpnos sveikatos moteris, našles [7]. 
6. Straipsnyje aptariamas XVII a. datuojamas Rakaučiznos senkapis savo antropologine medžiaga yra unikalus Lietuvos naujųjų amžių laidojimo paminklas. Nors tiesioginių istorinių žinių trūksta, tarpdalykinių tyrimų metu sukauptų duomenų visuma leidžia manyti, kad šiame senkapyje gausiai laidoti ir Pabaisko, esančio vos už trijų kilometrų, špitolès globotiniai bei pacientai.

Gauta 20140512

Priimta 20140610

\section{Šaltiniai ir literatūra}

[1] Pabaisko dekanato vizitacija 1782-1784 m., atlikta vyskupo Ignoto Jokūbo Masalskio paredymu. Parengè A. A. Baliulis. Lietuvos istorijos šaltiniai. T. IX. Vilnius: Lietuvių katalikų mokslo akademija, 2010.

[2] Lietuvos Metrika, Nr. 12 (1522-1529): Užrašymų 12 knyga. Parengè D. Antanavičius, A. Baliulis. Vilnius: Lietuvos istorijos institutas, 2001.

[3] Lietuva žemélapiuose. Sudare A. Bieliūnienè, B. Kulnytė, R. Subatniekienė. Vilnius: Lietuvos nacionalinis muziejus, 2011.

[4] KIAUPIENĖ, Jūratė; PETRAUSKAS, Rimvydas. Lietuvos istorija. Nauji horizontai: dinastija, visuomene, valstybè. Lietuvos Didžioji Kunigaikštystè 1386-1529. T. IV. Vilnius: Baltos lankos, 2009.

[5] BURBA, Domininkas. Smurtas bajorų šeimose XVIII a. Vilniuje. Šiaurès atènai [interaktyvus]. 2014, [Nr.] 19 [žiūretta 201402 26]. Prieiga per internetą: <http://www.satenai.lt/2014/01/22/ smurtas-bajoru-seimose-xviii-amziaus-vilniuje/>.

[6] KVIKLYS, Bronius. Pabaiskas. Mūsų Lietuva. Krašto vietoviu istoriniai, geografiniai, etnografiniai bruožai. T. II. USA: Lietuvių enciklopedijos l-kla, 1965.

[7] JAKULIS, Martynas. Špitolès - nuo prieglaudos iki ligoninès. Iš: 15 min [interaktyvus]. 2013, balandžio 24 d. [žiūrèta 201402 26]. Prieiga per internetą: <http://www.15min.lt/naujiena/ziniosgyvai/istorija/ldk-istorija-spitoles-nuo-prieglaudos-iki-ligonines-582-329346\#ixzz2vsqFLVe7> .

[8] ZABIELA, Gintautas. Pabaisko mūšio vietos aplinkos (Ukmergès r., Pabaisko seniūn.) $2006 \mathrm{~m}$. archeologinių žvalgymų ataskaita. Lietuvos istorijos instituto rankraščiu skyrius, f. 1, b. 4764.

[9] JANKAUSKAS, Rimantas; BARKUS, Arūnas; URBANAVIČIUS, Agnius. Preliminarūs 2006 m. archeologinių kasinèjimų antropologinès medžiagos tyrimų rezultatai. Iš: Archeologiniai tyrinèjimai Lietuvoje 2006 metais. Vilnius: Lietuvos archeologijos draugija, 2006.

[10] BLAŽEVIČIUS, Povilas. Rakaučiznos senkapis. Iš: Archeologiniai tyrinejjimai Lietuvoje 2012 metais. Vilnius: Lietuvos archeologijos draugija, 2013, p. 199-199.

[11] SVETIKAS, Eugenijus. Alytaus kapinynas: christianizacijos šaltiniai. Vilnius: Diemedžio l-kla, 2003.

[12] RÖSING, Friedrich Wilhelm; JANKAUSKAS, Rimantas. Infant deficit in premodern burial sites. In: 8 th Tartu International Anthropological Conference, 12-16 October 1997, Tartu, 1997, p. 5052.

[13] WALKER, Lee, Phillip et al. The Causes of Porotic Hyperostosis and Cribra Orbitalia: a Reappraisal of the Iron-Deficiency-Anemia Hypothesis. American Journal of Physical Anthropology 2009, vol. 139, p. 109-125.

[14] KNIEŽAITĖ, Milda. Senovès vilniečius kamavo ịvairiausios ligos Iš: Technologijos.lt. [interaktyvus]. [žiūreta 201405 5]. Prieiga per internetą: <http://www.technologijos.lt/n/mokslas/istorija_ir_archeologija/S-20060/straipsnis/Senoves-vilniecius-kamavo-ivairiausios-ligos?l=2\&p=1>.

[15] Welcome images [interaktyvus] [žiūrèta 201405 2]. Prieiga per internetą: <http://wellcomeimages.org/indexplus/obf_images/fa/33/a69c4106566896fe15db5ed698d3.jpg >. 


\section{POVILAS BLAŽEVIČIUS, JUSTINA KOZAKAITĖ, TOMA ZARANKAITÉ Reflections of the history of Špitole according to the
research data of the Old Cemetery of Rakaučizna
(Ukmergè District)}

Summary

The article is dedicated to the most recent cross-disciplinary research of the history of the Old Cemetery of Rakaučizna located $3 \mathrm{~km}$ from the small town of Pabaiskas (Ukmerge District). Though written sources contain no mention of this Old Cemetery dating to the 17th century, the Old Cemetery itself provides very interesting data on the locality under discussion. Therefore, to find out the reasons of origins of the numerous burials in Rakaučizna, the social status and the state of health of the people buried as well as other data important for reconstruction of the society, the article addresses the interconnections of Rakaučizna and Pabaiskas based on church, social and land-ownership aspects.

50 graves were found in the Old Cemetery dating to the 17th century during archaeological investigations. The interpretation of archaeological data leads to a conclusion that the people buried in the Old Cemetery were most likely rather poor and took up a rather low social status in society. In a way, it is also confirmed by anthropological investigations of the remains: as many as $60 \%$ of the buried people are children up to 12 years old; no graves of teenagers were found; young adults make up $6 \%$, while senior adults account for $34 \%$ of the graves.

The paleodemographic data of the Old Cemetery show that there were clearly too few children from 0 to 15 years old and too many adults from 20-25 to 50-55 years old in the reconstructed population. It testifies to the fact that the old cemetery represents a non-standard community or an exceptional period / events. It prompts a conclusion that a lot of children could pass away as a result of poor living conditions relating to local problems of the micro-region, which could have also been influenced by global factors.

The oldest historical sources dating back to the first half of the 16th century speak about Rakaučizna as an empty land; the locality is only referred to as a village at the end of the 18th century. Though there are few significant sources about the village with an old cemetery, we nevertheless find important information about the small town of Pabaiskas located barely several kilometres away and the shelter for the sick and poor, the Śpitole, which functioned in the 18th century next to the church built in the 15th century.

Considering an untraditional proportion of age groups of the people buried in the Old Cemetery of Rakaučizna, the high number of various traumas and infectious diseases, we can assume that the deceased buried in the Old Cemetery were also (or perhaps - only) the inhabitants and patients of the Špitole in Pabaiskas. It is also partly confirmed by the general information that more remote localities located at a greater distance from more populous places were often selected for the burial of the people who died in such shelters. Besides, in addition to treatment, Špitole also used to perform housing functions.

In conclusion, it can be stated that by its anthropological data, the Old Cemetery of Rakaucizna dating to the 17th century is a unique Lithuanian burial monument of the modern era. Though direct historical knowledge is lacking, the entirety of the data accumulated in cross-disciplinary research hints a conclusion that there was a tendency to bury the inhabitants and patients of the Špitole of Pabaiskas in this Old Cemetery as well. Key words: history of Špitole, old cemeteries, state of health of 17th century residents, daily life 